\title{
Gendering Migration: Kashmiri Girl's speaking On Right to Life and Education
}

\author{
Dr. Firdous Azmat Siddiqui \\ Asst. Professor,Sarojini Naidu Centre for Women's Studies, Jamia Millia Islamia, New Delhi
}

\begin{abstract}
Agar zameen pe kahi jannat hai to yahi hai, yahi hai, yahin hai
It was appropriately said about Kashmir, Paradise of the earth. But now it has become a battle ground for many, as some are fighting for protecting their motherland, some are fighting to claim their homeland and for many it's a war for separation. Undoubtedly in 'Firdaus' of Mughal emperor, Shahjahan, as being shatteredJism mera zhakhmon se bhara hai main kahan, kahan marham lagaoon
\end{abstract}

\section{Political Scenario in Kashmir:}

Urvashi Butalia traces its current ongoing conflict to harsh and repressive rule of the Dogra regime and the British rule. This was the period when Sheikh Abdullah emerged as a popular leader of the Kashmiri people demanding their homeland, while focusing the importance of the Muslim majority as a whole he never overlooked the significance of Kashmiri Hindu and Sikh in his political speeches. ${ }^{1}$ Others consider the year 1989 as a turning point when people's resent went on streets and the whole valley was covered with violence. Kashmiri people began to argue that they were not taken into account at the time of Kashmir's merger with India as it was the king's decision not the people's consent. According to Urvashi Butalia Kashmiri's popular leader Sheikh Abdullah was in prison when Dogra King Maharaja Hari Singh opted for India when he was proposed to choose between India and Pakistan. Just after the partition in the year of October 1947 Pakistan backed raiders had attacked Kashmir, subsequently the king took the help from the Indian Army at the cost of states' mergence with India a fact that was never liked by Muslim dominated Kashmiris. At that time it was agreed that once law and order had been restored in the state, the consent of the people of Jammu and Kashmir would be obtained. This of course never happened. And thus in post partition history shows the sharing of power between three key actors Hari Singh, Sheikh Abdullah and the Government of India. Jammu and Kashmir has been granted special status by article 370 of the Indian Constitution. This special provision given to Kshmir makes it different from other states of India, it led to a heated argument amongst politicians as right wing politician saw it as the appeasement policy of the Congress. And for the Kashmiris real azadi is still awaited; as consent of the people has not been taken so far as promised by the government. Hence 1947 onward Kashmir remained at the heart of the dispute between India and Pakistan. The dispute is for territorial ownership that led to several big and small scale wars between the two countries.

Kasmir once considered the most beautiful place of the earth is being burnt by its own people. There is hue and cry all around. All economic system has been paralyzed due to its disturbing situation. For days people do not get proper food despite of the money, they can afford but all is waste. The conflict is different from that of the North East; whereas in the North East Muslims belong to the poor sections. They are crying for roti, kapra and makan, their homes has been set on fire during the violence, they have lost all significant documents related to their land and property. Moreover situation becomes worse when they are being stigmatized as foreigner or Bangladeshi. How can they prove their authenticity? While in Kashmir, situation is different they do not have any label of being foreigner, they all claim to have their Kashmiri identity and this identity is not in question while for many North Easter Muslims their identity as Assamese is not acceptable by many Bodoland supporter as they are chatting slogan 'Hamara desh choro, Bangladeshi bhago-Bhago, as this was recounted by many rickshaw puller and domestic workers, recently settled as fresh migrant in Jamia Nagar Okhla. These new migrant has been pushed out violently by the supporter of the Bodoland. They are homeless without any penny. They came here as pauper and are being helped by some of their co villagers staying here much before their coming. It is very interesting to find these new settlers they are not choosing any stranger places instead they only selecting those plots and jhuggi areas where their relatives and co-villagers are residing; as they responded it is easy to get a place when you have a local connection. Also, as many sociologists suggest kinship is main reason behind this kind of settlement, it is based on relation, region and area. It's easy to assimilate with their own people instead of with strangers, as there are very clear divisions between the migrants from the north east and from other parts of north India, as they too says them as Bihari and Bengali. Although these North Eastern

\footnotetext{
${ }^{1}$ Butalia, Urvashi ed. Speaking Peace: Women's Voices from Kashmir, Kali for Women, Delhi, 2002, p.ix-x 
people speak Bengali they do not call themselves Bengali. For them Bengalis are those who are either illegal immigrant from Bangladesh or from West Bengal; as they claim, they are original inhabitant of Assam they were born and brought up in the North East for generations, they claim; in no way they have any connection with Bangladesh. They dub them below their status.

Migration has always two dimensions either pull or push. On the one hand Delhi attracts a number of migrants because of its political importance, as the capital of India, everyone aspire to have a space in Delhi. But on the other hand there are so many push factors that provide a space a large fleet from conflict and disturbed zone settle here. A person finds it a safe and secure place to survive with dignity. History of Delhi is filled with huge migration since centuries it remained capital of India. During the Sultanat period many people from Arab, Egypt, Turk, Central Asia and Afghanistan came here to settle permanently. They enjoyed a different social hierarchy, different from their own countries, it was based on their racial origin, they formed Irani groups, Turani groups, Turks, Pathans and most superior among those migrants were those who trace their origin from Prophet Muhammad called themselves as Saiyyid and those from their companion called sheikh. With passage of time they have been completely assimilated with Indian culture and were to a great extent, influenced by the Varna system of the Hindu, as they were categorized as Saiyyid, Sheikh, Mughal and Pathan and lowest among them are those who are converted from touchable and untouchable Hindus. These social compositions exist even to this day. Hence Delhi remained the centre of attraction for centuries and many people who came from overseas also migrated to other places of India as migrant and assimilate themselves with locals. And now again this reverse phenomenon is going on they are again heading towards Delhi. Indeed it would be right to say the history of Islam is replete with migration; persecuted by the Makkah pagans for thirteen years Prophet Muhammad commanded his follower to move to Madina as they found it difficult to practice and preach Islam in Makkah. Thus the term Hijrat has always a significant existence for Muslims. The Islamic calendar starts for the Hijrat of the Prophet to Madina. Even during the colonial period many Ulema sanctioned a Fatwa to migrate to other countries. The reason behind was not religious but political and economic as during the British period it were Muslims who suffers more than any community of India. And they find it difficult to get a respectable job. So they preferred to migrate to the adjacent part of India. During the Post partition period a large number of Panjabi Hindus and Sikhs settled in Delhi and afterwards it became tradition to come and reside in refugee camp. The late 1980s violence taking place in Kashmir valley forced many Kashmiris to leave the valley.

Kashmir has always been a burning issue. There are many personal experiences of different families living in Kashmir valley. Every person in the valley of paradise had faced curfew, blackouts, cross firing on the streets. If there is a paradise on earth, it is this, it is this, and it is this that became a day dream for the young student Reshma (name changed). Many surveys suggest how women of Kashmir are carrying the burden of conflict in forms of stress, trauma, depression, spontaneous abortions, miscarriages these are common problems the women of Kashmir are undergoing these days. ${ }^{2}$ The case of half widows is considerable the way they are facing day to day life. As Butalia narrates:

'Being without an earning member in the family meant they were forced to go out and seek work, but the moment they stepped out of the home, or stayed away from it, family members would accuse them of being women of bad character- a stigma that is difficult to live down, the more so when it is added to the stigma of widowhood. ${ }^{3}$

Reshma is a resident of Sri Nagar. She has migrated to Delhi for pursuing her higher education. She stayed here in Lajpat Nagar. She is doing BA Hons in Islamic Studies from a Central University. Reshma has migrated to Delhi with her mother while her father is back in Kashmir managing his ancestral business of export and import. She tells; 'I myself being from same background had tasted the socio-military life style of Kshmir. The so called paradise has became a military camp, in every area of the state, army bunkers are located and on roads there are army men one after another on a short distance.

My first experience was at the time of my birth, the whole valley was facing militancy. It was 1991 the entire Jammu and Kashmir was victimized. 1990s witnessed the evil of militancy at its peak but now days it has been minimized; however the fear still lurks in the psych of the every Kashmiri. In order to curb militancy, CRPF camps were setup in the whole valley, it was compulsory for every person to carry their identity cards with them as they could be asked anytime to show their identity proofs at any place, be it public place or their own house.

The CRPF entered into the houses of people and did long investigations from the family members especially from the male members because there was a misconception that the females used to hide male members of their houses. In these investigations male members were beaten very harshly and at times even killed. The entire society was living in a state of fear firstly because of the militancy and secondly because of the CRPF army

\footnotetext{
${ }^{2}$ Ibid. p. xiv

${ }^{3}$ Butalia, p.xv
} 
settlements in the valley. On the one hand innocents were tortured, on the other side most vulnerable group i.e. females were raped by the army forces but there was not a single woman to raise a voice against such cases.

There is not a single family who had not lost their near ones in the riots. Reshma Shares her personal experience perpetration committed by Army men as she lost her two cousins one after another from the same family. Her first cousin was shot dead in the Kargil war while the other cousin who went out to fill his B.Com admission form was killed in a cross firing in Lal Chawk area the main market of Sri Nagar. She asks 'What was his fault? What is the fault of several innocents killed in the streets for no reasons? Obviously, such a phenomenon affects both the entire fabric of the society. The entire tourism industry, the economic structure collapsed. The entire state is bleeds. The other affected group is consists of small kids and teenagers, their lives are at stake and their education too, every week there is a call of curfew by different parties leaders.' As far as the issue of education is concerned she thinks in Kashmir we have a very poor system of education it is very difficult to open schools are inordinately delayed, results long unnecessary vacations and classes affect the quality of education badly. Even times Education Board asked the students to complete 50\% of the course at home. So we hardly attend regular classes which results in huge migration of students from Kashmir to other places. Delhi is considered the best place for Kshmiri students. Reshma has so much anguish with the Army that she asks a very emotional question pertaining to the double standard of the Indian government, 'I want to raise a very simple question, when a peace march is held in the Kashmir valley army forces use real bullets but when the same peace march is held in Jammu the winter capital of the state rubber bullets are used instead. Is the life of people in Kashmir cheaper? Such incidents expose the intention of the government.' She is a very sensitive girl she says 'to burn things only a single spark is enough. In 2009 the whole valley was undergoing curfews, black outs, stone pelting for months. People had money but were not able to buy things even for their basic needs. During that time we had to eat dal and rice for several days. My mother used to add water in dal as there was nothing to eat and we had no other option but to compromise with situation. Only one hour was given to buy things during the curfew period. It appears People were living like refugees in their own mother land.'

Widespread violence affected not only matured persons, but also small kids. My four year old niece Zainah used to chat slogan- 'Ham Kea Chahte Azaadi'. For her may be azaadi is playing freely in her own house garden but she was stopped to do so because of the tear gas blast in small mohallas. She and other fellows of her age group knew nothing but still they were asked by their family members, not to go outside as the army force could kill anyone.

For me Azaadi is not only a single thing, it is a combination of things such as the freedom of going out with out fear of being raped, freedom of going out and coming back alive. For me it is a right to acquire education in a good atmosphere and lastly I want my motherland to be safe.

When I shifted to Delhi for my studies, the first time I heard a person calling me a terrorist, then it was shocking for me I replied politely 'Look I am a Muslim and after the twin tower attack at the USA all Muslims across the world became terrorist.' She believes aftermath of 9/11 situation of all Muslims became same though Kashmiri Muslims had to face more. They have sacrificed their sunnah of growing beard because they are treated like terrorist in their own country. At last I just want to say-

Khuda se mannat hai meri, lauta de jannat meri

Vo aman vo chaman ka nazaara

Ae Khudara lauta de Kashmir dobaara

She thus spoke on different aspects of Kashmiris' problem the way they are being victimized. Being a Kashmiri Muslim girl problem she had to face, the very life style had changed after getting admission in a reputed University of Delhi. I spent my childhood in a really different society, Kashmir being a disturbed area. Education was interrupted because of the riots going on and the most vulnerable group that was affected was the 'youth' opportunities were limited. My parent allowed me to go for further studies because education is good in other states of India. Not only Education other issues too affected the common people; life was paralyzed because of the riots, shutdowns, hurtles and the most important the CRPF Camps in the city which forced people to live in an army camp. Reshma says, 'When I came to Delhi or I can say mini India, where people for different states come with to create their own identities in different fields. For me it was and it is a bit difficult to handle things in Delhi, Firstly because of language. Some people belong to Bihar, Rajasthan, Kerela some to foreign countries Yemen, Mauritius, Nigeria and as a college student I experienced all flavours of language. Because of the language I face a type of awkward situation in many places be it my class room or any metro station or while talking to any auto driver or local rickshaw puller.

Secondly the issues of harassment eve teasing and other issues related to women are quite common. By now I have a lot of such experiences. I faced boys following me while going and coming for college or home and this though common is difficult for us. Only the pattern is different to I was in Kashmir I used to say such things to my brother and father and they would take action against those persons, but when I face such thing in Delhi I am told not to take it seriously and endure. If anything happens again we will see. This may be because 'I am Kashmiri.' Kashmir or Bihari all are same but the thing is Kashmiris are mostly given a different identity; 
they are dubbed as 'Militant'. First time when I listened to this word I took it non-seriously but later on when the word militant was used repeatedly for me I was aggrieved I told the After the case of 9/11 in America every Muslim be it Muslims from UP, Bihar, Delhi or Kashmir all are seen as the same so if every Muslim is involved in such an act so am. this is a fact that I am an Indian but there is a mind set in some people that Kashmiri's are not Indians, they are the supporters of Pakistan and this attitude must be changed.'

Reshma explain how being a Kashmiri she has to bear a lot of harassment. She opines Kashmiri women are most vulnerable group both at their state as well as in their newly adopted state as she shares a very horrible experience of her own. A boy saying to her things like if she did not accept his proposal that he loves her, he can do anything was shocking to her. She got furious and slapped him and in return she was tortured in these words 'oh you are Kashmiri and no one will help you if raped.' This was really a new thing for her it was the worst that could happen to her in Delhi.

Amina (name changed), she is also from Sri Nagar, J \& K. She stays here in Okhla for the past two years. Amiina says she stays in Jauhari Farm with her brother and mother. Her father stays in Sri Nagar and keeps them visiting after every three to four months. For Amina education standard over here is better than Sri Nagar this is the basic reason of her shifting here. Another important reason of her migration is the disturbing situation of Kashmir. She says, 'I would have never come to Delhi because my father was never interested in my studying away, but my father could not resist the situation and finally he agreed. I always wanted to go outside Kashmir for my higher studies because I wanted a sense of freedom, better education and exposure and was quite depressed when I was not allowed. When I shifted to Delhi, a lot of thing changed. I had to do things which I never did at my birth place. I live in a joint family in Sri Nagar and so I never had to bother about things like washing my clothes, going to the market and buying things required for the household, cleaning the house etc. but, Delhi made me do all this and I have to because there are three of us living together. I can say that shifting here made me responsible and independent to a large extent, but still some things is missing because my mother lives with me and I am very much dependent on her and cant do without her. That's why I prefer to live with her and not in the hostel.

Delhi gave her a lot of freedom in terms of going out and dressing but as she says she never took undue advantage of it because she don't want to deceive her father ever. She says, 'I never crossed my limits and never betray my faith. I thank the Almighty for making me a Muslim and giving me such parents who always inspired me to become a true Muslim. I have come closer to my religion because living in Delhi taught me there is nothing in this materialistic and fashionable world. The westernization gives you happiness but it is not the happiness in the real sense. The real happiness and peace of life lies in praying to Allah and following the mightiest religion Islam.'

26 year Old, Zarina, a migrant from Baramula district recollect those days when militancy was at its peak she says, 'once I was playing at my backyard then I heard heavy noise of Bombardment and shoot out, I did not puzzle because Bombardment was part of Kashmiri's life, I continued my play then a bullet came and crossed by touching my ear. I could not understand what happened to me and kept up my play. Then after few hour I felt a severe born at the verge of my right ear I ran into my house and said to brother look something is happended to my ear he looked at me and cried 'its bleeding.' He raise me in her arm and ran out of the house to look a hospital. There was a curfew, my brother was walking on the dead bodies lying on street and we reached hospital where I was given treatment.' For Zarina curfew, blackouts and bombardment was a normal routine of Kashmiri's life that is why she did not bother why this is happening while her ear was almost to damage. She was then six year old kid. Zarina says you cannot find any house in Baramula where they do not have lost their near and dear as her own aunt has to see her own son's encounter when she was in her namaz.

Zarina and many other Kashmiri girls' has left Kashmir to pursue their carrier and also in search of peace. Zarina has recently awarded with Ph.d degree from a renowned central University of Delhi and she left Delhi in January, 2013. She says now situation has normalize too much but after returning home she feels sorry again she has to enter in their native city in curfew as recently Jammu \& Kashmir again got disturbed. Zarina has given her interview in a very rush as on same day she has her flight to Baramula but she promised to send a detailed interview via mail. And after few days she sends me a mail:

\section{'Dear Madam}

I am extremely sorry for not being able to fulfill my word due to some of such circumstances to here. Perhaps you may be knowing that when I returned from Delhi the curfew was going on, but Allhamdolillah I and my brother reached safely to home. Since then I have not moved out from my house because of continous unrest here, for the killing of youth one by one. You were right that I may not be able to write anything after reaching home and the same happened. I have very less internet access here. Secondly our minds are so much disturbed that we are not able to do our daily routine works even coz we have lost the peace of mind. I am not exaggerating the things but telling you the reality. I am sending you the link of daily news paper from Kashmir to keep you update with the actual situation in Kashmir.' 


\section{Reference:}

[1]. Butalia, Urvashi, Speaking Peace: Women's Voice From Kashmir, Kali For Women, 2002

[2]. Butalia, Urvashi, Gender And Nation, Zubaan, 2008

[3]. Proceeding Of Two Day National Seminar On 'Governance And Security: India's North East And Bangladesh' Centre For North East Studies, Jamia Millia Islamia, New Delhi, 2009

[4]. Bearing Witness

[5]. Kannabiran, Kalpana And Ritu Menon, Feminist: From Mathura To Manormam:Resisting Violence Against Women Ijn India, 2006, Women Unlimited 